\title{
The Impact of Punishment on the Behaviour and Academic Work of Senior High School Students in the Ejisu- Juaben Municipality of Ashanti Region in Ghana
}

\author{
Eric Opoku-Adusei \\ Department of Educational Leadership, College of Technology Education, \\ University of Education, Winneba. Ghana \\ E-mail of corresponding author: zeuze1015@gmail.com
}

\begin{abstract}
The study sought to assess the impact of punishment on the behavior and academic work of senior high schools in the Ejisu-Juaben municipality of Ashanti region in Ghana. The researcher administered survey questionnaire to 150 teachers and 3666 students to collect data in three selected public senior high schools in the Ejisu-Juaben municipality. The research design adopted for this study was multiple case studies using the descriptive survey approach to examine the impact of punishment on the behaviour and academic work of senior high school students in Ejisu-Juaben Municipality of Ashanti Region in Ghana. Students should be counseled through awareness programmes to be polite and respectful to their teachers and obey school rules and regulations. Students should be intimated regarding the usefulness of punctuality, conduction of homework eschew making of noise in class, confirm health and hygiene, and should not quarrel with their school fellows. The results of the study indicated that incidence of misbehavior were frequently exhibited in schools by students. It was however recommended that teaching of Social Studies which includes life skills should be intensified in schools to equip learners with skills necessary in handling life challenges since human beings in their bit to make life face a lot of challenges in this world.
\end{abstract}

DOI: $10.7176 / \mathrm{DCS} / 11-7-02$

Publication date:July $31^{\text {st }} 2021$

\subsection{Introduction}

Punishment especially corporal punishment has received attention at the international community as a violation of a child's right. Most common students' behaviour problems include coming to school late, not doing assigned work, disrespecting teachers, skipping classes, stealing, and vandalizing school property (Manguvo, Whitney, and Chareka,.2011). Kilimci (2009) maintained that punishment is adopted worldwide in many schools. Krajewski, Martinek and Polka (1998) reported that not completing assignment, cheating in examinations attacks on teachers, stealing through force, carrying weapons, and sexual activity were the discipline problems among secondary school students.

Use of corporal punishment, according to Tan \& Yuanshan (1999) has been banned in some countries such as United States, Canada, Australia and lately in Hong Kong, and also in South African schools (Cicognani 2004). In Ghana, corporal punishment in schools is unlawful. Meanwhile corporal punishment is still lawful in homes and practiced in senior high schools both as a sentence for crime and as a disciplinary measure in public institutions (Newell, 2007).

Use of punishment especially corporal punishment has been argued as a means of correcting students. Some researchers (Straus 2003; Hyman 1990) are against the use of punishment as it is a maltreatment and psychological abuse of the student. They further condemned it pointing out its harmful effect such as somatic complaints, increase anxiety, changes in personality and depression. Gershoff (2002) stated that corporal punishment increases aggression, and lowers the level of moral internalization and mental health. Robinson et al. (2005) noted that running away, fear of teacher, feelings of helplessness, humiliation, aggression, and destruction at home and at school, abuse and criminal activities are the side effects of punishment. Punishment to Ghanaian children results to ocular injuries and other forms of pains (Oluwakemi \& Kayode 2007).

An individual's perception on the use punishment can be influenced by some socio-demographic factors like gender, religion, age, among others and teachers cannot be exempted. In Ghanaian schools especially pre-tertiary schools including senior high schools, punishments are mostly administered to students by the teachers. What are teachers' and students' perceptions towards the use of punishment as a means of correcting students' unwelcome behaviours in Ghanaian senior high schools? This study is designed to examine and find out the impact of punishment on the behaviour and academic work of senior high school students in the Ejisu- Juaben Municipality of Ashanti Region.

1.1 Statement of the Problem

An effective punishment system promotes positive behaviour and regular attendance (Ohene, 2006). It is the 
essential foundation for a creative learning and teaching environment in schools. Although current policy concerning violence in schools states that corporal punishment is banned (Ministry of Education, 1994), however, we find that it is being widely practiced in basic and senior high schools in Ghana as a common tool for discipline (Nasr, 2004). Possible reasons for expanding the use of punishment in senior high schools in spite of its legal ban could be administrative acceptance represented by the school and social acceptance represented by parents. This phenomenon is stirred by administrative acceptance represented by the school for not implementing the policy effectively; lack of communication with family; inability to find alternative means of discipline to teachers.

\subsection{Purpose of the Study}

The main purpose of this study is to examine the impact of punishment on the behaviour and academic work of senior high school students in the Ejisu-Juaben Municipality of Ashanti Region in Ghana. The following specific objectives were used to conduct the study:

1. To examine the incidence of indiscipline behavour shown by the students in the

Ejisu- Juaben Municipality.

2. To identify the various types of punishment meted to the students in the Ejisu- Juaben Municipality.

\subsection{Research Questions}

The study was guided by the following research questions which provided direction for the study.

1. To what extent does incidence of indiscipline behaviuor exist among students in senior high schools in the Ejisu- Juaben Municipality?

2. What types of punishments are usually meted out to indiscipline students in senior high schools in the EjisuJuaben Municipality?

\subsection{Hypotheses}

The study was also guided by the following null hypotheses.

Ho1: There is no significant relationship between punishment and good behaviour among students in the EjisuJuaben Municipality.

HA1: There is significant relationship between punishment and good behaviour among students in the EjisuJuaben Municipality.

\subsection{Theoretical Framework of the Study}

This study is based on two theories: the Traditional Behaviour Modification Theory and the Limit-Setting Theory. These theories explained the use of punishment in schools.

\subsection{Traditional Behaviour Modification Theory}

This study was based on the Traditional Behaviour Modification Theory advanced by Thorndike (1905 as cited in Busienei, 2012). The basic tenet of this theory is that learning depends on the events that occur after certain behaviour. Thorndike advanced the laws of effects according to which bahaviours that are rewarded tend to persist while those that are followed by discomfort or punishments tend to diminish. The theory is relevant to teachers who are givers of rewards and punishmentt in schools. Their aim is to shape the behaviour of the students. Corporal punishment has been one form of punishment applied in behaviour modification in schools.

\subsection{The Limit-Setting Theory}

The limit-setting theory incorporates Canter and Canter's (1992) “assertive discipline” and Jones's (2009) "positive discipline", which claim that children need to be controlled to behave properly through non-verbal cues, and parents and administrators can be used to gain control over student behaviour (Locke \& Lathan: 2006, p.1). The Limit-Setting Theory states that teachers have a right to impose order on students and students "need" adults to make it clear what we expect of them. Positive and negative consequences for individuals and the group as a whole will ensure that students comply with teachers' expectations. Alhassan (2000, p.7) and Wolfgang (2005) explained the premise of the assertive model as the right of the teacher to expect students to obey, with the full support of parents and administrators if needed. The teacher gives warnings, and then, if necessary, follows up with pre-established corrective actions, making it clear that the misbehaving student has chosen this negative corrective action by his or her own behaviour. Limit-setting stops misbehaviour. To put it simply, it is a request that says, "Stop what you are doing and do what I am telling you to do." It is to know how much power is appropriate to use in a given situation (Wolfgang, 2005). When the limit-setting fails, the teacher can declare that the learner's conduct is beyond her skills and abilities and the teacher can then seek the help of other teachers, and professionals like counsellors, psychologists and mental experts (Wolfgang, 2005).

This theory sounds punitive and autocratic in the sense that it emphasizes the imposition and instructions 
that must not be questioned and it is teacher centred in the sense that the learner must meet the teacher's expectations and the challenge with this approach is that it can make the learners rebellious. The theory does not clearly explain at what stage these limitations must be set, before or after consultations and collective agreements or must there be no consultations and agreements whatsoever.

\subsection{Conceptual Framework}

The conceptual framework was based on related reviewed literature to the study. The inputs of this study were the independent variables and included forms of punishment used in correcting infraction. Development of a well balanced pupil calls for the use of modes of correction that are not only friendly but also non -violent. The output indicated by student's level of discipline was the dependent variable.

Forms of punishment, both violent and non -violent were treated as independent variables. Effects of the use of use of the violent and nonviolent forms of punishment were treated as dependent variables while training of teachers was treated as the intervening variable. This study aimed at looking at the impact of corporal punishment on the behaviour and academic work of senior high school students. It is conceptualized that knowledge of the use of both violent and non- violent forms of punishment and the consequences of using each of the methods would lead to adoption of best practices in management of discipline in schools and consequently making learning environment warm and friendly to both the teachers and learners.

\subsection{Empirical Review}

The empirical review focused on the concept of punishment, types of punishment, and effects of punishment on the behaviour and academic work of students.

\subsection{Concept of Corporal Punishment}

Different scholars give different definitions of corporal punishment. Some confine it to the direct infliction of pain on the physical body and some take it beyond the physical to issues related to the child's deprivation of basic needs. Those who believe that it entails direct infliction of pain on the physical body see it as the "intentional or deliberate infliction of pain or discomfort and/or the use of physical force upon a student in order to stop or change behaviour and it includes hitting a child with the hand or with an object (such as a cane, belt, whip, shoe, etc.); kicking, shaking, or throwing the child; pinching or pulling hair; burning or scarring; forcing a child to stay or sit in uncomfortable or in undignified positions; excessive physical exercise; or humiliating physical activities in front of the class" (Duhaime, 2009, p.1, Finney, 2002, p.1 \& Kennedy, 2010, p.1). Ruptured eardrums, brain damage and other body injuries and even death are listed as some of the bad and tragic effects of corporal punishment, and Ghana is also reported to have such problems. Annually, children are reported of injuries like "broken arms, serious wounds and burst eardrums which are inflicted by teachers in both public and private schools" (Soneson \& Smith, 2005, p. 1). Vally (2005, p. 44) also confirmed that there is strong evidence that corporal punishment has placed children at risk of physical injury and this has resulted in many physical injuries such as bruising, swelling, cuts, and scrapes and because corporal punishment is easily abused, it has also led to very serious physical injuries like broken limbs, knocked out teeth, ruptured eardrums, damaged eyes, brain damage and internal injuries.

The Manifestation of Indiscipline in Students and Teachers Behaviour

Disciplinary problems that occur in schools are many and varied. Acts or manifestations of indiscipline are sometimes discussed based on their frequency in schools, how serious the given offences are and whether the disciplinary problem have reduced or worsened over time. An indiscipline student or group of students in reacting to an unpleasant situation in a school may overtly exhibit behavior which is inimical to the smooth running of the school.

Irwin and Nucci (2004) identified lying, stealing and cheating as acts of dishonesty among students. They explained that students tell lies in various degrees which reflect fear of failure, fear of a punitive, insensitive parent or a disturbed capacity to distinguish reality from fantasy. Also, when students steal, it may be as a result of monetary, lack of judgment or from misdirected peer influence. Millman, Schaefer and Cohen (2000) explained that stealing may represent hostility towards parents as an attempt to win attention. The tendency of stealing among students causing serious disciplinary problems is the possibility of hostile behaviour towards a suspected thief. Sometimes too, the guilty student remained unknown and teachers will punish an entire class or group for missing items.

\subsection{Types of Punishment in Schools}

There are various methods that have been applied in schools with some measure of success. Ndichu (2004) categorizes them into two: preventive and corrective.

Preventive measures aim at helping learners to do the right thing and avoid any form of behavior termed as undesirable by the school rules and regulations. These measures include guidance and counseling. They also 
include teacher's commitment to his or her professional expectations with dedication and love. It also involves provision studentse physical, psychological, emotional and intellectual needs by the school administration. In addition, it entails measures to ensure that schools principles of fairness, democracy and respect for student's freedom. This view is held by Griffin (1994) when he said that form four students at Starehe Boys' Centre are free to go out on Saturday in the afternoon after preps without leave out chit. As opposed to situations where students are strictly confined to school, when they are allowed out they go with a feeling of pride that they are trusted and are unlikely to commit crimes.

Ndichu (2004) noted that corrective measures are employed when preventive measures have failed and are aimed at correcting the offending student. They include a variety of measures. First, denial or withdrawal of privileges may be used. These privileges may include outings and popular leisure's. This is likely to work since many of these activities are held dear by many students. The learner can only be allowed to participate in these activities only with a promise of improvement. She/he will endeavour to improve so as not to miss the favourite activity.

\subsection{Legality of Corporal Punishment in Ghana}

Corporal punishment of children is lawful in Ghana, despite repeated recommendations to prohibit it by the Committee on the Right of the Child, Committee against Torture and during Ghana's initial Universal Periodic Review (UPR) in 2008 (Owen, 2012). Prohibiting corporal punishment is a key obligation under the Convention on the Rights of the Child and other international human rights instruments, though it is an obligation frequently ignored or evaded by governments. There has been no change in the legality of corporal punishment of children in Ghana since the state's initial UPR in 2008. Today, as then, corporal punishment is unlawful as a sentence for crime and in prisons, but it is lawful in the home, schools, alternative care settings and penal institutions such as borstal institutions and industrial institutions.

Corporal punishment is lawful in the home. The Children's Act of 1998 prohibits "cruel, inhuman or degrading treatment or punishment including any cultural practice which dehumanises or is injurious to the physical and mental well-being of a child" (article 13(1)) but allows for a degree of "reasonable" and "justifiable" punishment of children, stating that "no correction of a child is justifiable which is unreasonable in kind or in degree according to the age, physical and mental condition of the child and no correction is justifiable if the child by reason of tender age or otherwise is incapable of understanding the purpose of the correction" (article 13(2)). Provisions against violence and abuse in the Criminal Code of 1960, the Constitution (1992), the Domestic Violence Act of 2007 and the Children's Act are not interpreted as prohibiting all corporal punishment in child rearing.

\subsection{Reasons for Persistence Use of Corporal Punishment in Schools}

Various reasons have been advanced in support for the use of corporal punishment. Gaffney (1997) espoused a study of preservice teachers ${ }^{\text {ee }}$ beliefs about various issues and myths regarding use of corporal punishment. In his study, he looked at myths upon which corporal punishment has thrived. Among the reasons were:

i) Corporal punishment is time efficient.

ii) Corporal punishment attacks the problem head-on.

iii) All students dislike corporal punishment.

iv) Educators only use corporal punishment for the benefit of the students.

v) Corporal punishment prepares students to live in society that punishes those who break rules.

vi) Corporal punishment is a way of punishing those who misbehave.

vii) Corporal punishment leads to development of character.

viii) Corporal punishment teaches respect.

\subsection{Teachers' Perceptions on Corporal Punishment as a Method of Discipline in Schools}

The Convention on the Rights of the Child is the first legally binding international instrument to incorporate the full range of human rights-civil, cultural, economic, political and social rights. The Convention sets out these rights in 54 articles and two optional protocols. It voices the basic human rights that children everywhere have: the right to survival; to develop to the fullest; to protection from harmful influences, abuse and exploitation; and to participate fully in family, cultural and social life. The four core principles of the Convention are nondiscrimination; devotion to the best interests of the child; the right to life, survival and development; and respect for the views of the child. Every right stated in the Convention is inherent to the human dignity and harmonious development of every child. The Convention protects children's rights by setting standards in health care; education; and legal, civil and social services (UNICEF, 2009).

Agbenyega (2006) reported on the practice of corporal punishment in two basic schools in the Greater Accra District in Ghana. The findings revealed that an overwhelming majority of the teachers, 94 and 98 percent, use corporal punishment to enforce school discipline. The results further indicated that the majority of the 
teachers in both school sites administer corporal punishment to students who perform poorly in academic work. This implies that students with special learning problems who are not officially identified may be punished often for poor performance.

Education at any level is expected to influence behaviour of those who experience it. This applies to primary and secondary school pupils. These pupils react to happenings around them. Such happenings emanates from the changing nature of the society and the prevailing circumstances. These are physical, psychological, intellectual, emotional, educational, technological, economic, political and social changes all taking place at the same time.

\section{The Method}

\subsection{Research Design}

The research design adopted for this study was multiple case studies using the descriptive survey approach to examine the impact of punishment on the behaviour and academic work of senior high school students in EjisuJuaben Municipality of Ashanti Region in Ghana. The survey research, according to Saunders, Lewis and Thornhill (2007) is usually associated with the deductive approach.

\subsection{Population}

Fraenkel and Wallen (2006) defined population as any set of person or subjects that possess at least one common characteristic. According to Gay (1992) respondents in a population must possess the information required for the study. The study was limited to teachers and students of three senior high schools in Ejisu-Juaben Municipality of Ashanti Region. The target population size distribution in the study area was 68 teachers and 1036 students at Bonwire SHS, 83 teachers and 1485 students at Juaben SHS and 75 teachers and 1145 students at Ejisu SHTS.

\subsection{Sample and Sampling Procedure}

The total population size for the study was 3666 students and 226 teachers from three schools and a sample size of 150 and 51 teachers were sampled respectively and used for the study. One hundred and fifty students were randomly sampled because according to Amedahe and Asamoah-Gyimah (2014, p.45) "one to five percent of the population will be adequate for a study when the sample is well selected to be representative of the population."

\subsection{Data Collection}

Data was collected from primary sources. The primary source of data collection was the use of the questionnaire. In the administration of the questionnaire, majority of the activities was undertaken by me. This was done to ensure that portions of the items were explained to respondents to ensure their comprehension and high rate of return.

Table 1: Sample size distribution of teachers and students

\begin{tabular}{lllll}
\hline Schools & Teachers & \% Sampled & Student's Population & \% Sampled \\
\hline Bonwire S.H.S. & 68 & $16(25.0)$ & 1036 & $42(4.1)$ \\
Juaben S.H.S. & 83 & $18(21.7)$ & 1485 & $61(4.1)$ \\
Ejisu S.H.S. & 75 & $17(20.0)$ & 1145 & $47(4.1)$ \\
\hline Total & 226 & $51(22.1)$ & 3666 & $150(4.1)$ \\
\hline
\end{tabular}

\section{QUESTIONAIRE DATA}

The structure of the two questionnaires was made up of close ended items. The close-ended format offered the teachers and students fixed alternative responses from which respondents had to choose the option that was most applicable to them. The contents of the questionnaires were guided by research questions of the study. Both questionnaires contained 54 items, each covering background information on teachers and students, teachers' academic qualification and working experience. All the questionnaire that were distributed were analyzed using the SPSS statistical program of windows. The responses were then coded and subjected to complete item analysis to determine, among other things, the internal consistencies and validity of the instrument. The Cronbach alpha value was computed and used to test the reliability of the items on the questionnaire. A reliability coefficient of 0.71 was realized for the students' questionnaire and 0.78 for the teachers' one. This means the items on the two instruments were reliable since Fraenkel and Wallen (2006) asserted that "For research purposes, a useful rule of thumb is that reliability should be at .70 and preferably higher" (p.179).

\subsection{Data Analysis}

Data collected with the questionnaires were edited, coded and analysed using Predictive Analytic Software (SPSS version 16.0). The data were analysed by computing several sets of descriptive statistics in a form of frequencies, percentages, and means with their standard deviations. Pearson Moment Correlation analysis was 
carried out to establish if there is a linear relationship between punishment and indiscipline behaviour of students in senior high schools. Regression analysis was also carried out to find out what percentage of punishment account for students' misbehaviour. All level of test of significance was set at 0.05 alpha levels. The computed results were presented in tabular form for discussion.

\section{Results and Discussions}

The presentation of the results involved analysis of the main data, interpretation of the analyzed data and discussion of the findings. The results were presented in two parts. The first part dealt with analysis of the demographic characteristics of the respondents whilst the second part dealt with analysis of the main data of the study.

\section{Demographic Characteristics of the Respondents}

The demographic characteristics which were relevant to this study were gender of the students and teachers, ages of the students and teachers and teaching experience of the teachers. The gender distribution of the students and teacher used for the study is shown in table 2 .

Table 2: Gender Distribution of students and teachers

\begin{tabular}{lllll} 
& Students & & Teachers & \\
Gender & Freq. & $\%$ & Freq. & $\%$ \\
\hline Male & 60 & 40.0 & 35 & 68.6 \\
Female & 90 & 40.0 & 16 & 31.4 \\
\hline Total & 150 & 100.0 & 51 & 100.0 \\
\hline
\end{tabular}

As shown in Table 2, 60 (40.0\%) out of the 150 students used were males whilst the remaining $90(60.0 \%)$ students were females. On the other hand, $35(68.6 \%)$ of the teachers used to conduct the study were males whilst the other $16(31.4 \%)$ were females. From the result it could be seen that more female students were used to conduct the study than males whilst more male teachers were used than female teachers to conduct the study. The study looked at the age distribution the students. Table 3 presents the age distribution of the students.

Table 3: Age Distribution of the Student

\begin{tabular}{lcc}
\hline Age (years) & Frequency & Percentage \\
\hline $13-15$ & 10 & 6.7 \\
$16-18$ & 123 & 82.0 \\
$19-21$ & 16 & 10.7 \\
22 and above & 1 & 0.7 \\
\hline Total & 150 & 100.0 \\
\hline
\end{tabular}

Table 3 indicated that majority of the students used to conduct the study, $123(82.0 \%)$ were between the ages of 16-18 years whilst only $10(6.7 \%)$ and $16(10.7 \%)$ other students were between the ages of $13-15$ years and $19-21$ years respectively. Thus, most of the students used for the study were between the ages of $13-21$ years. Students in this age bracket were supposed to be in senior high school according to the system of education in Ghana (Antwi, 1992). The system of education in Ghana according to Antwi (1992) is six years primary education, of senior high school and four years of University education. Based on the above system, a student in senior high school should be between the ages of $16-19$ years. This showed that majority of the students used for the study were in senior high school.

The study also explored the age distribution of the teachers. The ages given by the teachers are shown in Table 4.

Table 4: Age Distribution of the Teachers

\begin{tabular}{lll}
\hline Age (years & Frequency & Percentage \\
\hline $25-30$ & 11 & 21.6 \\
$31-35$ & 13 & 25.5 \\
$36-40$ & 15 & 29.4 \\
$41-45$ & 4 & 7.8 \\
Above 45 & 8 & 15.7 \\
\hline Total & 51 & 100.0 \\
\hline
\end{tabular}

The results presented in Table 4 showed that 11(21.6\%) and 13(25.5\%) of the teachers used for the study were between the ages of 25 - 30 and 31 - 35 years respectively whilst 15(29.4\%) years and above 45 years respectively. Majority of the teachers used for the study were 25 years and above. Teachers in this age bracket are in the active working group and in one way or another might have punished students who showed indiscipline behaviour either in the classroom or outside the classroom.

The teaching experiences of the teachers were sought during the study. Table 5 shows the various years that the teachers have taught. 
Table 5: Number of years Teachers have taught

\begin{tabular}{lcc}
\hline Number of years taught & Frequency & Percentage \\
\hline $1-5$ & 13 & 25.5 \\
$6-10$ & 15 & 29.4 \\
$11-15$ & 3 & 5.9 \\
$16-20$ & 9 & 17.6 \\
Above 20 & 11 & 21.6 \\
\hline Total & 51 & 100.0 \\
\hline
\end{tabular}

As presented in Table 5, 13(25.5\%) of the teachers have taught for $1-5$ years, whilst $15(29.4 \%)$ others have taught for $6-10$ years. In addition, whilst only $3(5.9 \%)$ of the teachers have taught for $11-15$ years, as many as $9(17.6 \%)$ and $11(21.6 \%)$ others have taught for $16-20$ years and above 20 years respectively.

The number of years taught as shown in Table 5 indicated that most of the teachers, 38(74.5\%), have taught for six years and above. Teachers who have taught for six years and more might have witnessed various forms of punishments meted to students and the effects of each punishment on the academic performance of the students. The responses of the teachers with these considerable teaching experiences could provide valid data for the study.

\section{Analysis of the Main Data and Discussion of the Findings of the Study.}

This session dealt with analysis of the main data and results of the study as well as discussion of the findings. The results were presented in line with the research questions and hypotheses formulated to guide the study. The results were presented using frequencies percentages and means with their standard deviations.

Research Question One: To what extent dues incidence of indiscipline behavior exist among students in senior high schools in the Ejisu - Juaben Municipality?

The study sought from both students and teachers incidence of indiscipline behavior among students in Senior High Schools used for the study. The various incidence of students' indiscipline behavior provided the students are shown in Table 6.

Table 6: Incidence of Students' Indiscipline behavour as Reported by the Students

\begin{tabular}{llc}
\hline Type of Misbehaviour & Mean & Standard Deviation \\
\hline Stealing of other students belongings & 4.74 & 0.69 \\
Bullying of junior students & 4.42 & 1.94 \\
Possession of unprescribed kits and gadgets & 4.16 & 1.07 \\
Cheating during test and examination & 3.91 & 1.20 \\
Dodging classes (truancy) & 3.79 & 1.20 \\
Going out of school without permission & 3.63 & 1.18 \\
Fighting / quarrelling & 3.55 & 1.30 \\
Smoking / substance abuse and alcoholic drink & 2.85 & 1.27 \\
Sexual misconduct & 2.72 & 1.32 \\
Strikes demonstration and riots & 2.35 & 1.1 \\
\hline
\end{tabular}

As shown in Table 6, the mean score of incidence of student's misbehaviour ranges from stealing of other student's belonging $($ mean $=4.74 ;$ std $=0.69)$ to strikes, demonstration and riots $($ mean $=2.345 ;$ std $=1.18)$. The response to the various misbehaviour, however, show variations from strongly agreed to strongly disagree.

The results presented in Table 6 indicated that students strongly agreed to the presence of incidence of stealing other student's belonging, which had a mean score of 4.74 with a standard deviation of 0.69 . Stealing is one of the offences in the code of discipline for students in senior high schools. Once there is an incidence of stealing among the students in the schools used for this study, the needed sanctions have to be applied and hence students have to be subjected to various form of punishments to deter others. This finding of the study confirms those of Alhassan (2013), who asserted that students are punished by teachers or school administrators for wrong done against rules and regulations of the schools. The rules and regulations of the school include stealing of other student's belongings or other people who are not part of the school system. 
Table 7: Incidence of Indiscipline Behaviour among Student as given by Teachers

\begin{tabular}{|c|c|c|c|c|c|c|c|c|c|c|}
\hline Strongly Ag & ree & $\mathrm{Ag}$ & ree & Not S & $\mathrm{D}$ & isagree & & Strong & Disag & \\
\hline Statements & Freq & $\%$ & Freq. & $\%$ & Fred & $\%$ & Freq. & $\%$ & Freq. & $\%$ \\
\hline Stealing of other & & & & & & & & & & \\
\hline Student's belongings & 23 & 45.1 & 22 & 43.1 & 1 & 2.0 & 2 & 3.9 & 3 & 5.9 \\
\hline Strikes, demonstration & & & & & & & & & & \\
\hline $\begin{array}{l}\text { and riots } \\
\text { Bullying of junior }\end{array}$ & 2 & 3.9 & 9 & 17.6 & 11 & 21.6 & 16 & 31.4 & 13 & 25.5 \\
\hline Students & 18 & 35.3 & 26 & 51.0 & --- & --- & 2 & 3.9 & 5 & 9.8 \\
\hline $\begin{array}{l}\text { Cheating during } \\
\text { test and examination }\end{array}$ & 17 & 33.3 & 27 & 52.9 & 1 & 2.0 & 4 & 7.8 & 2 & 3.9 \\
\hline $\begin{array}{l}\text { Going out of school } \\
\text { without permission }\end{array}$ & 13 & 25.5 & 29 & 56.9 & 2 & 3.9 & 4 & 7.8 & 3 & 5.9 \\
\hline Fighting / quarrelling & 8 & 15.7 & 27 & 52.9 & 9 & 17.6 & 1 & 2.0 & 6 & 11.8 \\
\hline Sexual misconduct & 9 & 17.6 & 24 & 47.1 & 9 & 17.6 & 3 & 5.9 & 6 & 11.8 \\
\hline $\begin{array}{l}\text { Smoking, substance } \\
\text { abuse and drinking } \\
\text { of alcohol }\end{array}$ & 4 & 7.8 & 21 & 41.2 & 13 & 25.5 & 4 & 7.8 & 9 & 17.7 \\
\hline $\begin{array}{l}\text { Possession of } \\
\text { unprescribed kits }\end{array}$ & & & & & & & & & & \\
\hline and gadgets & 15 & 29.4 & 21 & 41.2 & 7 & 13.7 & 5 & 9.8 & 3 & 5.9 \\
\hline Dodging classes & 15 & 29.4 & 22 & 43.1 & 5 & 9.8 & 5 & 9.8 & 4 & 7.8 \\
\hline
\end{tabular}

As shown in Table 7, as many as 45 out of 51 teachers, representing $88.2 \%$, agreed that there is incidence of student stealing other students' belongings in their schools, whilst only $5(9.8 \%)$ teachers disagreed that there was no incidence of students stealing other student's belongings and one teacher was not sure if such incidence of stealing was prevalent in the school. The results, thus, indicated that there was incidence of students stealing other students belongs in the senior high schools used for the study.

Research Question Two: What types of punishments are usually meted out to indiscipline students in the study area?

The researcher sought from both teachers and students the various types of punishments given to students when they flange or fringe on school rules and regulations. Table 8 provides a summary of student's responses on the punishments meted to them when they disobeyed school rules and regulations.

Table 8: Types of punishments given to students as provided by the student's themselves

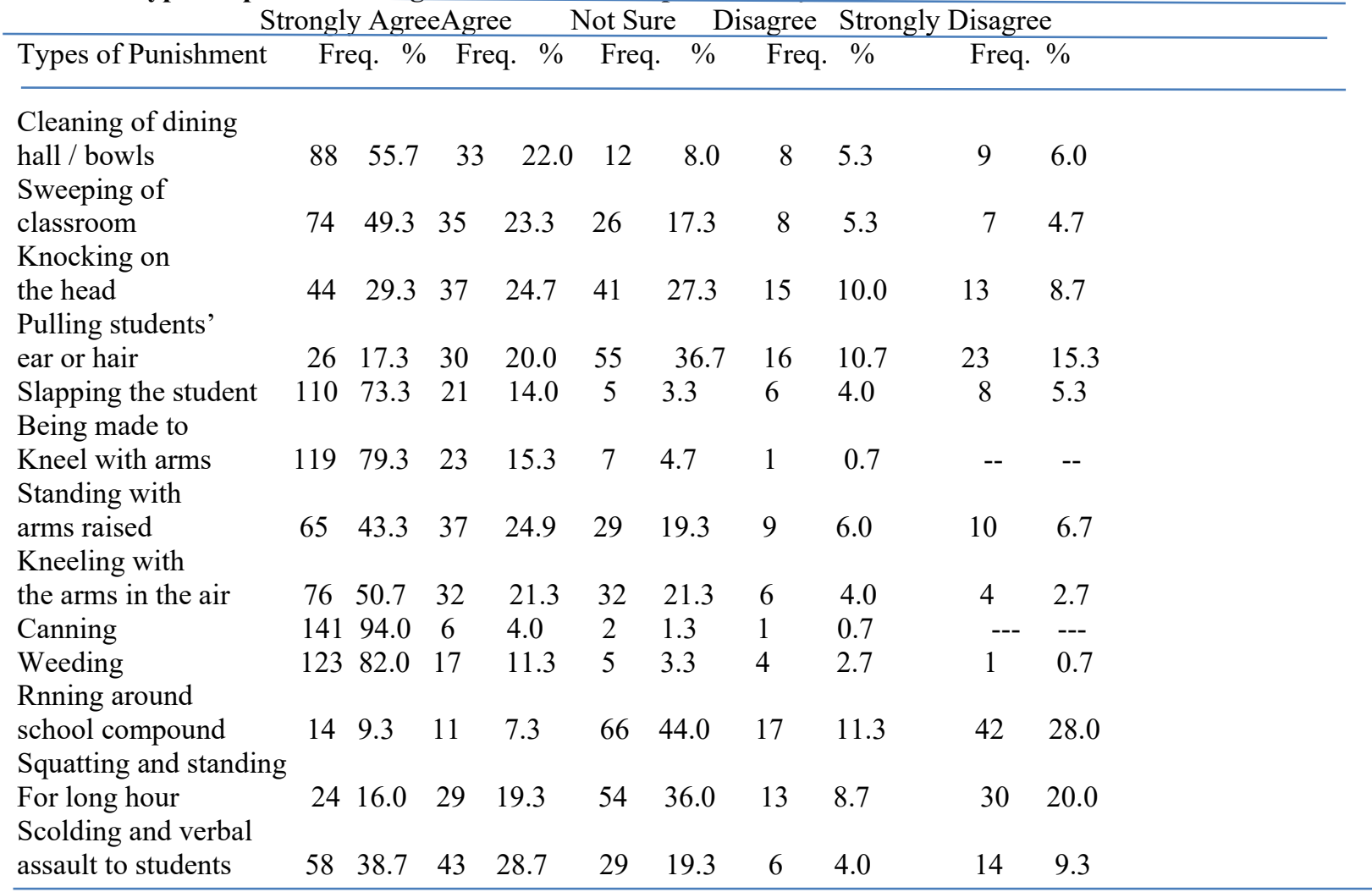


Table 8 showed that the students were given different forms of punishments when they flout school rules whilst $121(77.7 \%)$ of the students agreed that they were made to clean the dining hall / bowls when they misbehaved in the school, only $17(11.3 \%)$ of the students disagreed to the statement and $12(8.0 \%)$ of the students were not sure of such punishments being meted to students. With regard to sweeping of classroom, $74(49.3 \%)$ and $35(23.3 \%)$ students strongly agreed and agreed respectively that they were made to sweep the classroom when they disobeyed school rules.

Teachers perception on the types of punishment they give to students were examined. Table 9 showed the various types of punishment given by the teachers.

Table 9. Teachers' perceptions of types punishment they give to students

\begin{tabular}{lll}
\hline Types Of Punishment & Mean & Standard Deviation \\
\hline Sweeping of class & 4.29 & 0.97 \\
Canning & 4.08 & 0.77 \\
Cleaning of dining hall /bowl & 4.02 & 0.64 \\
Weeding & 3.69 & 1.09 \\
Being made to kneel down & 3.69 & 1.09 \\
Standing with arms raised & 3.10 & 1.37 \\
Kneeling with the arms in the air & 3.02 & 1.39 \\
Running around school compound & 2.76 & 1.37 \\
Squatting and standing for long hours & 2.18 & 1.38 \\
Scolding and verbal assaulting students & 2.16 & 1.33 \\
Knocking on the head & 1.98 & 1.12 \\
Pulling students ear or hair & 1.75 & 0.84 \\
Slapping the student & 1.49 & 0.78 \\
\hline Means of Means & 2.94 & 1.09 \\
\hline
\end{tabular}

The teacher's responses to the various types of punishments they meted to students showed different levels of agreements and disagreement, with their means scores ranging from 4.29 to 1.49 with standard deviation of 0.97 and 0.78 respectively. The response to the various punishment scored different means and standard deviations.

The results shown in Table 9 indicate that the teachers strongly agreed to asking students to sweep their classroom (mean 4.29, std=0.97), canning (mean=40.08, std=0.77) and cleaning of dining hall/bowls (mean=4.02, std $=0.64$ ) when students fringe on the school rules and regulations, these types of punishments are among those commonly given to disobedient students in senior high schools.

The teachers also agreed that they punish students to weed certain portion of the compound (mean=3.69, $\mathrm{std}=1.09$ ) and make them to kneel down (mean=3.67, $\mathrm{std}=1.19)$ when they flout school rules and regulations. However, the teachers were not sure they ask students to stand with arms raised and kneeling with the arms in the air. The teachers' response to these two punishments had a mean score of 3.10 with a standard behavior of 1.39. The teachers response should that they never punish students by asking them to stand with arms raised or kneel down with the arms raised in the air.

Concerning running around school compound as a punishment students misbehaved, the teachers disagreed that they meted out such punishment to students (mean=2.76 and std=1.37). The teachers also strongly disagreed that they give students punishment such as squatting and standing for long hours, scolding and verbally assaulting students, knocking students head, pulling students ear or hair and slapping them. The teachers' responses to this punishment scored a mean in the range of 2.18 to 1.49 with their standard deviations.

The teachers' responses to the types of punishments they give to their students are in line with the code and ethics of regulations for punishing students in senior high schools. The code of ethics for punishing students for bid teachers from slapping students, knocking students head or pulling their ears and hair.

The students response to some punishments meted to them by their teachers are different from the teachers' responses. For instance, most of the students strongly agreed that their teachers slapped them (mean $=4.75$, $\mathrm{std}=1.4$ ) when they disobeyed school rules and regulations. It seems that the students were exaggerating the punishments being meted to them by their teachers. However, punishments such as canning, weeding, cleaning of dining hall/ bowls given by the students as punishments meted to them are consistent with those of the punishments indicated by the teachers as given to students.

\section{Testing of Hypotheses}

The hypothesis formulated to guide the study was tested using correlation and regression analysis. Correlation analysis was conducted to examine the relationship between independent variable (punishment) and the dependent variables good behaviour among students and academic works or classroom learning.

Ho1: There is no significant relationship between punishment and good behaviuor among students in the Ejisu- Juaben Municipality. 
HA1: There is significant relationship between punishment and good behaviour among students in the Ejisu- Juaben Municipality.

Table 14: Correlation between Corporal Punishment, students' behaviour and academic work

\section{Variables}

Corporal punishment 1

Students behavior 0.73

1

The result in Table 14 showed that there is significant relationship between punishment and student behaviour as well as punishment and students' academic work at 0.01 level (2tailed). Table 14 showed that independent variable (corporal punishment) is positively correlated with students' behaviour which is significant at $\mathrm{p} \leq 0.01$. Based on the result, the null hypothesis (Ho1) which stated that there is no significant relationship between punishment and good behaviuor among students in the study area is rejected but the alternative hypothesis (HA1) which indicated that there is significant relationship between punishment and good behaviour among students in the study area is accepted.

Regression analysis was used to test the research hypothesis. The result for each variable obtained is presented in the table that follows:

H01. There are no statistically significant relationships between corporal punishments and students behavior in the study area.

HA1:There is significant relationship between punishment and good behaviour among students in the study area. The result of the regression analysis carried out is shown in Table 15.

Table 15: Regression Analysis of Corporal Punishment and Students' behaviour

\begin{tabular}{llllll}
\hline Variables & R-square & t-value & Coefficient & F-value & P-value \\
\hline Corporal Punishment & 0.612 & 14.33 & 0.71 & 26.0 & 0.00 \\
\hline
\end{tabular}

Table 15 indicated that the value of coefficient beta is calculated as 0.71 . That is, there is a significant relationship between the variables; the value of R-square is calculated as 0.612 showing $61.2 \%$ on the dependent variables (students' behaviour) is explained by independent variables (corporal punishment). The models goodness of fit shown by F- value was 26.0. Hence, H01 hypothesis which stated that "there is no statistically significant relationships between corporal punishments and students behavior in the study area was rejected. As found above, $61.2 \%$ of students change in behaviour in the schools used for the study were accounted for by punishments.

HO2: There is no statistically significant relationship between corporal punishment and students' academic work (classroom learning) in the study area.

HA2: There is significant relationship between punishment and academic work among students in the study area. Table 16 shows the result of the analysis of the data obtained.

Table 16: Regression Analysis of Corporal Punishment and students' academic works (classroom learning)

\begin{tabular}{lccccc}
\hline Variables & R-square & t-value & Coefficient & F-value & P-value \\
\hline Corporal Punishment & 0.641 & 15.21 & 0.56 & 21.2 & 0.00 \\
\hline
\end{tabular}

As shown in Table 16 above, the value of the coefficient beta is measured as 0.56 . That is there is a significantly negative relationship between punishment and academic work. The value of R- square is calculated as 0.641 showing $64.1 \%$ variation in the dependent variable (academic works) is explained by independent variable (coporal punishment). The models goodness of fit shown by F- value was 21.2. Therefore hypothesis (HO 2) which showed that there is no statistically significant relationship between corporal punishment and students' academic work was rejected. The results showed that corporal punishment was negatively correlated with students' academic work. The results showed that students who are physically punished develop negative attitude towards learning such students develop poor attention span become depressed and emotionally unstable. These findings of the study support those of Roussow (2003), According to Roussow (2003), students who received corporal punishment show symptoms' of dejection in their studies, poor performance in tests and also do not participate in the teaching learning process enthusiastically.

\section{REFERENCES}

Adesina, S. I. (1980). Introduction to educational planning. Ile-Ife: University of Ife Press.

Afifi, T. O. (2012). "Physical punishment and mental disorders: Results from a nationally representative US sample". Pediatrics, 132(7), 2-12.

Agbenyega, S. J. (2006). Corporal punishment in the schools of Ghana: Does inclusive education suffer? The Australian Educational Researcher, 33(3), 107- 122.

Alhassan, A. B. (2013). How can we foster the mental health of the teacher and school children. Zaria, Nigeria: Tamaza Publishing Company.

Alhassan, A. B. (2011). Concise modern dictionary of educational psychology. 
Zaria, Nigeria: Tamaza Publishing Company.

Alhassan, A. B. (2000). Understanding educational psychology. Zaria, Nigeria: Tamaza Publishing Company.

Alhassan, A. B., Aboagye, J. K. \& Kankam, G. (2000). "Indiscipline and corporal punishment in Ghanaian schools: A psychological examination of policy and practice". Ghanaian Educational Media and Technology Association Journal, 3, 7-16.

Akinboye, J. O. (1992). Behaviour therapy and other treatment strategies. Ibadan, Paperback Publishers.

Amedahe, F. K. \& Asamoah-Gyimah, E. (2014). Introduction to educational research. Accra: Mercury Press

American Academy of Pediatrics (1998). "Guidance for effective discipline".

New York: Longman Group of Companies.

Ampah, A. A. (1998). Indiscipline in the senior secondary schools in the Cape Coast Municipality. Unpublished B.Ed dissertation presented to the faculty of education, University of Cape Coast.

Andero, A. A. \& Stewart, A. (2002). Issues of Corporal Punishment: Re-examined. Journal of Instructional Psychology, 29, 90-96.

Antwi, M. K. (1992). Development of education in Ghana 1880-1990. In C.O.

Abosi and J. Brookman-Amissah (Eds.), Introduction to education in Ghana (Pp. 11-27). Accra: Sedco Publishing Limited.

Arif, M.S. (2007). The effects of corporal punishment and psychological treatment on student learning behaviour. Journal of Theory and Practice in Education, 3(2), 171-180.

Aziz, M. (2010). Should high school students be required to volunteer in community service projects. South Africa: Accessed on 14th March, 2015 from http//www.helium.com.

Banda, L. H. (2010). Negative effects of corporal punishment on children:

Zambian view. Accessed on 25th June. 2015 from http://www.ync.com.

Balogun, O. A. (2009). A philosophical defence of punishment in traditional African legal culture: The Yoruba example. Journal of Pan African Studies, 3 (3), 43-54.

Baumrind, D. (1996). A blanket injunction against disciplinary use of spanking is not warranted by the data. Pediatrics, 98(4), 19-25.

Beltran, M. (2002). Parenting tips: The importance of consistency. Retrieved on 6th December, 2014 from $\mathrm{http} / / \mathrm{www}$.essortment.com/family/parentingtipsiszdp.htm.

Bermard, H. W. (1992). Mental health for classroom teachers. New York: Mcgraw Hill Book Company.

Benatar, D. (1998). Corporal punishment-social theory and practice. Journal of Social Philosophy, 24 (1), 1-30.

Benatar, D. (2004). Corporal punishment philosophical study. Accessed on 12 December, 2014 from www.corpun.com/benatar.html.

Benatar, D. (2009). Corporal punishment. Cape Town: University of Cape Town.

Berk, L. E. (2009). Child development. New York: Pearson Education.

Bott, S. (2012), Violence against women in Latin America and the Caribbean: A comparative analysis of population-based data from 12 countries. Washington D.C: Pan American Health Organisation \& Centers for Disease Control and Prevention.

Brenner, V. \& Fox, R.A. (1998). "Parental discipline and behaviour problems in young children". Journal of Genetic Psychology, 159(2), 251-256.

Busienei, J. A. (2012). Alternative methods to corporal punishment and their efficacy. Journal of Emerging Trends in Educational Research and Policy Studies, (JETERAPS) 3 (2), 155-161.

Cameron, M. (2006). Managing school discipline and implications for school social workers: A review of literature. National Association of Social Workers, 28(4), 219- 228.

Canter, L., \& Canter, M. (1992). Assertive discipline: Positive behaviour management for today's classroom. Santa Monica: Lee Canter Associates.

Cast, A. D. (2006), “Childhood physical punishment and problem solving in marriage”, Journal of Interpersonal Violence, 21, 244-261.

Cavanagh, K. \& Dobash, P. (2007), "The murder of children by fathers in the context of child abuse”, Child Abuse \& Neglect, 31, 731-746.

Cheng, H. G. (2011) "Childhood physical punishment and the onset of drinking problems: Evidence from metropolitan China". Drug and Alcohol Dependence, 118, 31-39.

Cherian, V. I. (1994). "Self-reports of corporal punishment by Xhosa children from broken and intact families and their academic achievement". Psychological Reports, 74(3), 867-874.

Cicognani, L. (2004). "To punish or discipline? Teachers' attitude towards the abolition of corporal punishment". M.Ed. thesis, University of the Witwatersrand, Johannesburg.

Compact Oxford English Dictionary. (2008). Punishment. Oxford: Oxford University Press.

Contreras, M. (2012), Bridges to adulthood: Understanding the lifelong influence of men's childhood experiences of violence, analyzing data from the international men and gender equality survey. Washington, D.C: International Center for Research on Women (ICRW). 
Conte, A. E. (2000). In loco parentis. Alive and Well Education 121,(1), 1-5.

Coyl, D. D. (2002). "Stress, maternal depression, and negative mother-infact interactions in relation to infant attachment". Infant Mental Health Journal, 23(1), 145-163.

Creswell J.W. ( 2004). Research design: Quantitative and qualitative approaches. California: Sage Publications.

Curwin, R. L.,\& Mendler, A. N. (1998).Discipline with dignity. New York: Association for Supervision and Curriculum Development

Davidoff, S. \& Lazarus, S. (2002). The learning school: An organization development approach. Landsdowne: Juta \& Co.

Day, R. D., Peterson, G. W., \& McCracken, C. (1998). "Predicting spanking of younger and older children by mothers and fathers". Journal of Marriage and Family, 60, 79 - 94.

Dobbs, T. (2005) Insights: children \& young people speak out about family discipline. Auckland: Save the Children New Zealand.

Duhaime, L. (2009). Corrective force: Spanking takes a spanking. Accessed on 30th August, 2014 from http//www.duhaime.org.

Durrant, J. E. (2004), Joint statement on physical punishment of children and youth. Ottawa: Coalition of Physical Punishment of Children and Youth.

Du Preez, P., Campher, T., Grobler, B., Loock, C., \& Shaba, S.M. (2002). Principles of effective education management. Sandown: Heinemann Publishers (Pty) Ltd.

Edumadze, E. (2004). Banning of corporal punishment has contributed to indiscipline, Ghana News Agency, 10 March, 2004. p.1.

Eggleton, T. (2001). Discipline in the school. Eric Digest, 2, 1-13.

Egwunyenga, E. J. (2009). "Corporal punishment and disciplinary control of secondary school students in Delta State”. Journal of Research In National Development, 2 (7) 197-208.

Etesi, M..Z. (2010). Time tested strategies of curbing student indiscipline in learning institutions. Nairobi: Shrend Publishers ltd.

Finney, D. (2002). Corporal punishment in schools. Accessed on 3rd January, 2015 from http//www.uhr.org.

Flynn, C. P. (1998). "To spank or not to spank: The effect of situation and age of child on support for corporal punishment". Journal of Family Violence 13, 21 - 37.

Flynn, C. P. (1996). Regional differences in spanking experiences and attitudes: A comparison of northeastern and southern college students. Journal of Family Violence, 11(1), 59-80.

Fraenkel, R.J. \& Wallen E.N. (2006). How to design and evaluate research in education. Illinois: F.E. Peacock Publishers, Inc.

Gay, L.R. (1992). Educational research: Competencies for analysis and application. New York: Macmillan Press.

Gershoff, E. T. (2002). Corporal punishment by parents and associated child behaviours and experiences: A meta- analytic and theoretical review. Psychological Bulletin, 124(4). 128.

Gershoff, E. T. \& Bitensky, S. H. (2007), "The case against corporal punishment of children: Converging evidence from social science research and international human rights law and implications for US public policy". Psychology, Public Policy and Law 13(4), 231 - 272.

Ghana News Agency. (2011). Corporal punishment in Ghanaian schools. Accra, Ghana.

Ghana News Agency. (2012). Punishment meted to basic school studenst. Accra, Ghana.

Gladwell, A. (1999).A survey of teachers' attitudes towards corporal punishment after abolishment of corporal punishment in South Africa.Unpublished M. Ed dissertation, University of Durban.

Gnagey, W. J. (1998). The psychology of discipline in the classroom. London:Macmillan Company.

Gregan-Kaylor, A. (2004). The effects of corporal punishment on anti-social behaviour in children. National Association of Social Workers, 28 (3), 153-162.

Griffin, G. (1994). School mastery. Nairobi: General Printers.

Gottfredson, D. G. (1999). Developing effective organizations to reduce school disorder. Washington, D.C,: Office of Educational Research and Improvement.

Grote, R. C. (2006). Discipline without punishment: The proven strategy that turns problem employees to superior performers. New York: AMACOM.

Hamblin, D. (1998). The teacher and pastoral care. Oxford: Blackwell.

Hastings, N. \& Schwieso, J. (1987). New direction in educational psychology: Behaviour and motivation in the classroom. London: The Falmer Press.

Human Rights Watch (1999). Spare the Rod: Corporal punishment in Kenyan schools. September, 11(6), 4-6.

Hyland, P. (2012). "Beating and insulting children as a risk for adult cancer, cardiac disease and asthma", Journal of Behavioural Medicine, 29, 20-32.

Hyman, I.A. (1995). Corporal punishment psychological maltreatment, violence, and punitive in America. New York: Research Advocacy and Public Policy. Applied and Preventive Psychology. 
Hyman, I.A. (1997). Corporal punishment psychological maltreatment, violence, and punitive in America. New York: Research Advocacy and Public Policy. Applied and Preventive Psychology.

Irwin, L.,\& Nucci, C. (2004).Perceptions of students' locus of control of discipline among preserves and inservice teachers in multiculturalclassrooms..Intercultural Education, 5 (1), 59-71.

Jones, L. (2012). "Prevalence and risk of violence against children with disabilities: A systematic review and meta-analysis of observational studies". The Lancet, 12, 20-32.

Kamugane, L. F. (2008). Impact of the ban on corporal punishment on students' discipline in secondary schools in Nembure Division of Embu District, Kenya Unpublished M.Ed. Project, Kenyatta University, Nairobi.

Kennedy, R. (2010). An interview with Jordaan risk on corporal punishment. Accessed on 13th September, 2014 from http//www.about.com.

Kerr, D. C. R. (2004). "Parental discipline and externalizing behaviour problems in early childhood: The role of moral regulation and child gender". Journal of Abnormal Child Psychology, 32(4), 369-383

Kerr, D. C., Lopez, N. L., Olson, S. L \& Sameroff, A. J. (2004). Parental discipline and externalising behaviour problems in early childhood: The roles of moral regulation and child gender. Journal of Abnormal Child Psychology, 32(4), 383- 390.

Khewu, P. D. N. (2012). Practices in the alternatives to corporal punishment strategy being implemented in selected primary schools in Buffalo City Metro Municipality: Implications for school leadership. Unpublished Ph. D, University of Fort Hare.

Kilimci, S. (2009). Teacher's perceptions on corporal punishment as a method of discipline in elementary schools. Journal of International Social Research, 2(8), 243-251.

Kochanska, G. (2001). The development of self regulation in the first four years of life. Child Development, 72(4), 1091-1111.

Kopansky, T. M. (2002). Corporal punishment in schools: A hit or miss proposition. Tennessee School Journal, 3, 24-30.

Krajewski, B., Martinek, P. D., \& Polka, B. (1998). "Designing creative discipline: Tough, but well worth it". Positive Discipline, 3, 7 - 13.

Kuppuswamy, B. (2002). Advanced educational psychology. New Delhi, India: Longman Group Ltd.

Larzelere, R. E. (1996), "A review of the outcomes of parental use of non abusive or customary physical punishment". Pediatrics, 98(4), 824-828.

Larzelere, R. E., \& Smith, G. L. (2000). Controlled longitudinal effects of five disciplinary tactics on antisocial behaviour. Paper presented at the meeting of the American Psychological Association, Washington, DC.

Lau, J. T. F. (1999). "Prevalence and correlates of physical abuse in Hong Kong Chinese adolescents: A population-based approach”, Child Abuse \& Neglect, 23, 549-557.

Leary, C. E. (2008). "Parental use of physical punishment as related to family environment, psychological wellbeing, and personality in undergraduates". Journal of Family Violence, 23, 1-7.

Linke, P. (2002). Physical punishment: What does the research say? Every Child, 8(3), 28-29.

Locke, A. \& Lathan, G. P. (2006). The theory of goal setting and task performance. South Bay: Prentice Hall.

Loeber, R. (2000) "Stability of family interaction from ages 6 to 18”. Journal of Abnormal Child Psychology, 28(4), 353-369.

Lopez, N. (2001). "Parental disciplinary history, current levels of empathy, and moral reasoning in young adults", North American Journal of Psychology, 3,193-204.

Lunkenheimer, E. S. (2006). "The intergenerational transmission of physical punishment: differing mechanisms in mothers' and fathers' endorsement?" Journal of Family Violence, 21,509-519.

Macharia, J. W. (2005). Specific challenges facing guidance and counseling teachers in public secondary schools in Kiambaa Division of Kiambu District. Unpublished M.Ed dissertation, Nairobi, Kenyatta University.

McNamara, E. (1996). The effectiveness of incentive and sanction systems used in secondary schools: A behavioural analysis. Research Review, 10(56), 20-25.

Manguvo, A., Whitney, S. D., \& Chareka, O. (2011), "The crisis of student misbehaviour in Zimbabwean public schools: teachers' perception on impact of macro socioeconomic challenges". International Journal of Educational Administration and Policy Studies, 2(4), 40 - 44.

Martin. T. \& Stein, H.D. (2012). Paediatrics and adolescent medicine, Journal Watchdog, 3, 23-26.

McClure, T. E. \& May, D. C. (2008), "Dealing with misbehaviour at schools in Kentucky: Theoretical and contextual predictors of use of corporal punishment". Youth \& Society 39(3), 406 - 429.

Miller, A. (1987). For your own good : Hidden cruelty in child-rearing and the roots of violence. London: Virago.

Millman, H.W., Schaefer, C. E., \& Cohen, J. J. (2000).Therapies for school behaviour problems: A handbook for practical interventions. San Fransco: Jossey-Bass Publishers.

Ministry of Education. (1994). Unified code of discipline for basic education schools. In Head teachers' 
handbook, (257-262). Accra, Ghana: Ministry of Education.

Moles, O. (1999). Strategies to reduce student misbehaviour. Washington D.C.: Office of Educational Research and Improvement.

Mugambi, M. J. (2013). An assessment of the extent of use of corporal punishment in secondary schools in Muthambibi Division in Maara district, Tharaka Nithi county, Kenya. Unpublished dissertation for M.Ed. degree, Kenyatta University, Nairobi, Kenya.

Mundy-Castle, A. C. (1996). Psychology and the search for meaning. Inaugural Lecture, University of Lagos, Inaugural.

Mushoriwa, T. D. \& Shumba, A. (2002). Self-perceived and measured study strategies among college students. South African Review of Educational Journal, 2(1), 46- 49.

Mwamwenda, T.S. (2004). Educational psychology: An African perspective. Durban: Butterworths.

Nakpodia, E. D. (2012). Principals' attitude towards corporal punishment in Nigeria secondary schools. Global Journal of Human Social Science Linguistics \& Education, 12 (11), 50- 59.

Nasr, S. (2004). "Violence among students in school, some psychological variables". Washington, D.C: The National Center for Social and Criminal research.

Neuter, R. (2011). Physical punishment may impair child's cognitive functions. psych central. Retrieved on 12th December 2014 from psychocentral.com/news.

Ndichu, M. F. (2004). An examination of philosophical foundations of corporal punishment in Kenyan education. Unpublished M.Ed. thesis. Kenyatta University, Nairobi.

Newell, P. (2007). "Briefing from global initiative to end all corporal punishment of children". Briefing for the Committee on the Elimination of Discrimination Against Women Pre-session Working Group (July 2007) States to be Examined in the 41st Session.

Oduro, G. (2006). Head-teachers role modelling in african schools: The challenge of communal values. Paper presented to 9th EMASA Annual Conference, 6-8 February 2006. Aventura, Bela, Bela, Limpopo.

Ohene, S. (2006). "Parental expectations, physical punishment, and violence among adolescents who score positive on a psychosocial screening test in primary care", Pediatrics, 117(2), 441-447.

Oluwakemi, A. B. \& Kayode, A. (2007). "Corporal Punishment-related Ocular Injuries in Nigeria Children". Journal of Indian Association of pediatric Surgeon, 12(2), 76 - 79.

Okumbe, J. A. (2007). Educational management: Theory and practice. Nairobi: Nairobi University Press.

Owen, S.S. (2012). The relationship between social capital and corporal punishment in schools: A theoretical inquiry. Youth and Society, 37, 85-112.

Porteus, K., Vally., S. \& Ruth, T. (2005). Alternatives to corporal punishment: Growing respect and discipline in the classrooms. Sandown: Heinemann Publishers

Price, T. (2007). A step forward: Positive behaviour support and school social work practice. School Social Work Selection, 2, 44-56.

Ramsburg, D. (1997). The debate over spanking. ERIC Digest, 13, 97.

Republic of Ghana. (1992). Constitution of the Republic of Ghana. Accra. Assembly Press.

Reynolds, D. (1987), School factors and truancy. New Society, 37(720), 223-228.

Robinson, D. H., Funk, D., Beth, A., \& Bush, A. M. (2005), "Changing beliefs about corporal punishment: Increasing knowledge about ineffectiveness to build more consistent moral and informational beliefs". Journal of Behavioural Education 14(2), 117 - 139.

Rosen, L. (1997). School discipline: Best practices for administrators. California: Corwin Press.

Roussow, J. P. (2003). Learner discipline in South African public schools: A qualitative study. Koers, 68(4), 413-435.

Saunders, M., Lewis P. \& Thornhill, A. (2007). Research methods for business students. London: Prentice Hall Limited.

Save the Children (2001). Ending corporal punishment of children: Making it happens. A paper submitted to the UN committee on the Rights of children for its General Discussion Day on Violence against children in school \& within the family. Ghana.

Scarr, S. (1995). Southern parents spank children more than northern parents, Study finds. Accessed on 20th September, 2014 from gopher://minerva.acc.Virginia.

Slee, R. (1995). Changing theories and practices of discipline. London: Falmer Press.

Socolar, R. R. S. \& Stein, R. E. K. (1995), "Spanking infants and toddlers: Maternal belief and practice". Pediatrics 95, $105-111$.

Shumba, A. \& Moorad, F. (2001). A note on the laws against child abuse in Botswana. Botswana Journal of African Studies, 14 (2), 175-181.

Shumba, A. (2003). Pupil physical abuse by secondary school teachers in Zimbabwe: A child-rearing practice or cultural dilemma? Journal of Aggression, Maltreatment \& Trauma, 8(4), 143-159.

Smith, A.B., Gollop, M.M., Taylor, N.J \& Marshall, K.A. (2004).The discipline and guidance of children: A 
summary of research. Dunedin, NZ: Children's Issues Centre.

Smith, J.R. \& Brooks-Gunn, J. (1997). "Correlates and consequences of harsh discipline for young children". Archives of Pediatrics \& Adolescent Medicine, 151(8): 777- 786.

Soneson, U. \& Smith, C. (2005). Ending corporal punishment of children in South Africa. Arcadia: Save the Children of Sweden.

Stommel, M. \& Wills, C. E. (2004). Clinical research: Concepts and principles for advanced practice nurses. Philadelphia: Wolters Kluwer.

Straus, M. A. (2001). Beating the devil out of them: Corporal punishment in American families and its effects on children. New Brunswick: Transaction Publishers.

Straus, M. A. (2003). The primordial violence: Corporal punishment by parents, cognitive development, and crime. Walnut Creek, CA: Alta Mira Press.

Straus, M. A. \& Mathur, A. K. (1995) "Corporal punishment of adolescents and academic attainment". Paper presented at the annual meeting of the Pacific Sociological, San Francisco, 7 April, 1995.

Straus, M. A. \& Gimpel, H. S. (1992). "Corporal punishment by parents and economic achievement: A theoretical model and some preliminary empirical data", Paper presented at the 1992 meeting of the American Sociological Association.

Straus, M. A. \& Paschall, M. J. (2009). "Corporal punishment by mothers and development of children's cognitive ability: A longitudinal study of two nationally representative age cohorts", Journal of Aggression, Maltreatment \& Trauma, $18,459-483$

Straus, M. A. \& Douglas E (2008), "Research on spanking by parents: Implications for public policy" The Family Psychologist: Bulletin of the Division of Family Psychology, 43 (24), 18-20.

Talwar, V. (2011). "Effects of a punitive environment on children's executive functioning: A natural experiment". Social Development, 20(4), 805-824.

Tan, E. \& Yuanshan, C. (1999). "Discipline problems in schools: Teachers' perception". Teaching and Learning, 19(2), $1-12$.

Taylor, C. A. (2012). "Use of spanking for 3-year-old children and associated intimate partner aggression or violence", Pediatrics, 126(3), 415-424.

Trocmé, N. (2013). Physical abuse and physical punishment in Canada. Montreal: Canadian Welfare Research Portal Information Sheet.

Twum-Danso, A. (2010), Children's perceptions of physical punishment in Ghana. Accra: Nuffield Foundation.

UNICEF( 2009). Convention on the rights of the child. Accessed on 21st October, 2014 from http://www.unicef.org/crc/.

UNICEF. (2010). Child disciplinary practices at home: Evidence from a range of low- and middle-income countries. New York, NY: UNICEF.

United States. (2010). "Corporal punishment in schools and its effect on academic success". Hearing before the Subcommittee on Healthy Families and Communities Committee on Education and Labour. US House of Representatives 111th Congress, Second Session Held in Washington DC on April 15, 2010.

Umezinwa, R. N. \& Elendu, I. C. (2012), "Perception of teachers towards the use of punishment in Sancta Maria primary school. Onitsha, Nigeria: Education and Practice Press.

Vally, S. (2005). Corporal punishment and bullying: The rights of learners. Durban, South Africa: Education Rights Project.

Vally. S. (1998). Spare the rod and spoil the child. Educators Voice, 2(8), 3-5.

White, M. A. (1995). Natural rates of teachers' approval and disapproval in classroom. Journal of Applies Behaviour Analysis, 8, 367-372.

Williamson-Maloy, R. (2010). Discipline. Accessed on 16th June, 2014 from url:http//onchildrenstopics.com.

Wissow, L.S. (2002). Child discipline in the first three years of life in America: Challenges facing parents with young children. New York: Cambridge University Press.

Wolfgang, C.H. (2005). The three faces of discipline for the elementary school teacher: Empowering the teacher and students. London: Allyn \& Bacon. 